\title{
Section 5
}

\section{Data relating to political systems}

\section{THE COUNTRIES OF WESTERN EUROPE}

\section{Austria}

Population 8.1 million (2000)

Capital Vienna

Territory 83,857 sq. km

GDP per capita US $\$ 25,788$ (2000)

Unemployment 3.7 per cent of workforce (2000)

State form Republic. The Austrian constitution of 1920, as amended in 1929, was restored on 1 May 1945. On 15 May 1955, the four Allied Powers signed the State Treaty with Austria, ending the occupation and recognising Austrian independence. Current head of state President Thomas Klestil (took office 8 July 1992, re-elected 1998).

State structure A federation with nine provinces (Länder), each with its own constitution, legislature and government.

Government The president appoints the prime minister (chancellor), and, on the chancellor's recommendation, a cabinet (Council of Ministers) of around fifteen members. The Council of Ministers is responsible to the lower chamber of Parliament, the 183-member National Council (Nationalrat). The second chamber, the 64-member Federal Council (Bundesrat), is elected by the Parliaments of the Länder. The government, or individual ministers, can be removed from office by a vote of no confidence in the National Council. The Federal Council has the power to delay legislation, but not to veto it. For certain important matters, the two chambers meet together as the Bundesversammlung. Certain matters may be subject to a referendum. The constitutional court (Verfassungsgerichtshof) determines the constitutionality of legislation and executive acts.

Current government The 1999 election brought to an end the 13-year government coalition between the Social Democratic Party of Austria (SPÖ) and Austrian People's Party (ÖVP), which had been under considerable strain. When the two parties failed to reach a coalition agreement, Austria found itself short of viable alternatives. The record gains of the radical right Freedom Party of Austria (FPÖ) had changed the balance of power within the party system. The other two numerically viable coalitions SPÖ/FPÖ or ÖVP/FPÖ - had been ruled out in advance by the two mainstream parties. An attempt by the SPÖ to form a minority government failed. Finally, a coalition was formed between the ÖVP and FPÖ under Wolfgang Schüssel (ÖVP) and reluctantly sworn in by President Klestil on 5 February 2000. The decision to form a government including a party of the far right six of the 12-member cabinet were FPÖ members - provoked international outrage and a period of sanctions imposed by the European Union.

Electoral systems The president is elected by direct universal suffrage for a term of six years and may not serve more than two terms.

Elections to the Nationalrat are based on a system of proportional representation, the 'enforced' preference voting system, with a 4 per cent threshold. Term of office: four years. 
Austrian presidential elections, 19 April 1998

\begin{tabular}{lc}
\hline & Votes (\%) \\
\hline Thomas Klestil (independent, backed by ÖVP and & 63.4 \\
$\quad$ FPÖ) & \\
Gertraud Knoll (SPÖ) & 13.6 \\
Heide Schmidt (LF) & 11.1 \\
Richard Lugner (independent) & 9.9 \\
Nowak & 1.9
\end{tabular}

Election to the Austrian Nationalrat, 3 0ctober 1999

\begin{tabular}{lcc}
\hline & Votes (\%) & Seats \\
\hline Social Democratic Party (SPÖ) & 33.1 & 65 \\
People's Party (ÖVP) & 26.9 & 52 \\
Freedom Party (FPÖ) & 26.9 & 52 \\
Greens & 7.4 & 14 \\
Liberal Forum (LF) & 3.6 & 0 \\
Others & 2.1 & 0 \\
Total & & 183 \\
\hline
\end{tabular}

Party system Since the Second World War, the Austrian party system has been dominated by the SPÖ and ÖVP, which, until the general election of 1990, together took 90 per cent of the vote. The Greens emerged in the early 1980s, and, in 1986, the FPÖ became a serious electoral force under the charismatic leadership of Jörg Haider. A controversial figure, Haider has in the past expressed approval of the National Socialist (Nazi) regime in Germany. On 28 February 2000, Haider unexpectedly resigned as party leader of the FPÖ, ostensibly as a conciliatory gesture to its coalition partner the ÖVP, but he remains acknowledged as the de facto leader of his party.

\section{Belgium}

Population 10.3 million (2000)

Capital Brussels

Territory 30,519 sq. km

GDP per capita US\$26,570 (2000)

Unemployment 7.0 per cent of workforce (2000)

State form Constitutional monarchy.

Belgium seceded from the

Netherlands in 1830, and the constitution of 1831 established
Belgium as a 'unitary decentralised state'. Between 1970 and 1993 a four-stage process of constitutional reform transformed the country into a federation and culminated in the new Belgian constitution of 1994.

Current head of state King Albert II (sworn in 9 August 1993).

State structure A federation

characterised by three linguistic communities (French-, Flemish- and German-speaking), three regions (Walloon, Flemish and Brussels) and four linguistic regions

(French-speaking, Flemish-speaking, German-speaking and the bilingual region of Brussels-Capital). The unusually complex federal arrangements are designed to contain the conflicts between the country's linguistic communities.

Government The monarch appoints a formateur to negotiate the formation of a new government. The monarch appoints the prime minister, and, on the prime minister's advice, a cabinet of up to fifteen members comprising an equal number of Flemish and French speakers. Executive power is nominally held by the monarch, but in practice is exercised by the cabinet. The cabinet is responsible to the lower chamber of Parliament, the Chamber of Representatives. Since the constitutional reform of 1993, the upper chamber of Parliament, the Senate, has had only limited legislative powers.

Current government The outgoing christian-social four-party coalition of CVP/PSC/PS/SP under Jean-Luc Dehaene (CVP) had been in government since 1988 but had made losses at each subsequent election. Its heavy defeat in June 1999 was seen as a public response to a range of scandals including an ongoing health-related scandal concerning contaminated feed for livestock and the earlier paedophile scandal of 1996. The series of scandals had 
rocked the establishment and had provoked calls for a democratic renewal in Belgium. A new 'purple-green' (ie, red, blue and green) coalition comprising six parties (VLD/PRL-FDF-MCC/SP/PS/AGALEV/ ECOLO) was formed on 12 July 1999 led by Guy Verhofstadt (VLD). It was the first government to exclude the christian democratic parties since 1958.

Electoral systems A constitutional amendment of 1993 altered the membership of the two chambers of Parliament. The Chamber of Representatives formerly had 212 members and now has 150; the Senate formerly had 182 members and now has 71 .

Elections to both chambers are by a system of proportional representation for a four-year term. However, only forty of the Senate's seventy-one members are directly elected; the remaining thirty-one are co-opted from the councils of the linguistic communities. In May 1995 elections were held for the first time to the new assemblies for the regional/linguistic communities and to the Brussels assembly. These assemblies each have a term of office of five years.

Elections to the Belgian Chamber of Representatives, 13 June 1999

\begin{tabular}{|c|c|c|}
\hline & Votes (\%) & Seats \\
\hline $\begin{array}{l}\text { Flemish Liberals and Democrats } \\
\qquad \text { (VLD) }\end{array}$ & 14.3 & 23 \\
\hline Christian People's Party (CVP) & 14.1 & 22 \\
\hline Walloon Socialist Party (PS) & 10.1 & 19 \\
\hline Liberal Reform Party (PRL-FDF-MCC) & 10.1 & 18 \\
\hline Flemish Bloc & 9.9 & 15 \\
\hline Flemish Socialist Party (SP) & 9.6 & 14 \\
\hline ECOLO (Walloon Greens) & 7.3 & 11 \\
\hline AGALEV (Flemish Greens) & 7.0 & 9 \\
\hline Social Christian Party (PSC) & 5.9 & 10 \\
\hline People's Union & 5.6 & 8 \\
\hline National Front (FN) & 1.5 & 1 \\
\hline Others & 4.6 & 0 \\
\hline Total & & 150 \\
\hline
\end{tabular}

Elections to the Belgian Senate, 13 June 1999

\begin{tabular}{lcc}
\hline & Votes (\%) & Seats \\
\hline Flemish Liberals and Democrats & 15.4 & 6 \\
$\quad$ (VLD) & & \\
Christian People's Party (CVP) & 14.8 & 6 \\
Liberal Reform Party (PRL-FDF-MCC) & 10.6 & 5 \\
Walloon Socialist Party (PS) & 9.7 & 4 \\
Flemish Bloc & 9.4 & 4 \\
Flemish Socialist Party (SP) & 8.9 & 4 \\
ECOLO (Walloon Greens) & 7.4 & 3 \\
AGALEV (Flemish Greens) & 7.1 & 3 \\
Social Christian Party (PSC) & 6.1 & 3 \\
People's Union & 5.1 & 2 \\
National Front (FN) & 1.5 & 0 \\
Others & 4.0 & 0 \\
Total & & 40 \\
\hline
\end{tabular}

Party system Reflecting Belgium's linguistic divide, each of the main ideological families in Belgium is represented by two separate parties: the christian democrats by the Flemish CVP and Walloon PSC; the socialists by the Flemish SP and Walloon PS; the liberals by two recently 'renovated' groupings, the Flemish VLD (formerly PVV) and Walloon PRL-FDF; and the Greens by the Flemish AGALEV and Walloon ECOLO. In addition, there are many protest and fringe groups, of which the most significant are the extreme right-wing Flemish Bloc, the more moderate Flemish Nationalist People's Union, and the extreme right Walloon National Front. With the electorate's rejection of the christian-social coalition in June 1999, the liberal parties emerged as the largest 'political family' for the first time since 1883. For the first time since the 1920 s, the christian and socialist families no longer held a combined majority in Parliament. The Green family gained ground while the far right family's standing was eroded overall. New parties demanding a complete overhaul of the political system failed to gain a seat in the federal Parliament. 


\section{Denmark}

Population 5.3 million (2000)

Capital Copenhagen

Territory 43,075 sq. km

GDP per capita US $\$ 28,448$ (2000)

Unemployment 4.7 per cent of workforce (2000)

State form Constitutional monarchy, based on the constitution of 5 June 1953.

Current head of state Queen

Margrethe II (succeeded to the throne 14 January 1972).

State structure Unitary. Home rule was granted to the Faroe Islands in 1948 and to Greenland in 1979.

Government The monarch appoints the prime minister and, on the advice of the prime minister, the cabinet of around twenty members, which is responsible to the unicameral Parliament (Folketing). Legislative authority rests jointly with the monarch and Parliament. A bill adopted by the Folketing may be submitted to referendum on the request of one-third of the members of the Folketing. The bill is invalid if it is rejected by a majority of the votes cast, provided this represents at least 30 per cent of the electorate.

Current government On 31 October 2001 Prime Minister Poul Nyrup Rasmussen (SDP) called an early general election in what critics saw as an attempt to capitalise on the popularity of his support for the US-led campaign against Afghanistan. The gamble backfired and the SDP suffered losses which cost the party its customary position as the largest party in the Folketing. The defeat led to the transfer of government to the former opposition centre-right. Helped by the parliamentary votes of the right-wing $\mathrm{DF}$, a new minority government was formed comprising the liberals (V) and conservatives (KF), led by Anders Fogh Rasmussen (V). Electoral systems The Folketing has a maximum of 179 members, two of whom are elected in the Faroe Islands and two in Greenland. The Folketing is elected by a system of proportional representation for a term of office of four years.

Election to the Danish Folketing, 20 November 2001 (excluding representatives from the Faroes and Greenland)

\begin{tabular}{lcc}
\hline & Votes (\%) & Seats \\
\hline Liberal Party (V) & 31.3 & 56 \\
Social Democratic Party (SDP) & 29.1 & 52 \\
Danish People's Party (DF) & 12.0 & 22 \\
Conservative People's Party (KF) & 9.1 & 16 \\
Socialist People's Party (SF) & 6.4 & 12 \\
Social Liberals (RV) & 5.2 & 9 \\
Red-Green Unity List (ELRG) & 2.4 & 4 \\
Christian People's Party (KrF) & 2.3 & 4 \\
Total & & 175
\end{tabular}

Party system The main parties currently fall into two broad groupings of centre-right $(\mathrm{V}, \mathrm{KF}, \mathrm{KrF})$ and centre-left (SDP, RV, SF and ELRG). The far-right DF was founded in 1995 following a split within the Progress Party (FP). Since the centre-right government depends on its support for a parliamentary majority, the DF now holds a key position within the party system.

\section{Finland}

Population 5.2 million (2000)

Capital Helsinki

Territory 338,145 sq. $\mathrm{km}$

GDP per capita US $\$ 24,414$ (2000)

Unemployment 9.7 per cent of workforce (2000)

State form Republic. Finland was part of the Kingdom of Sweden until 1809 when it became an autonomous Grand Duchy under the Russian Empire. During the Russian Revolution of 1917 Finland claimed its independence and, after a brief civil war, the republic was founded in 1919. Finland's founding republican constitution of 17 July 1919 was replaced with a new constitution on 1 March 2000. 
Current head of state President Tarja

Halonen (took office 1 March 2000).

State structure Unitary

Government In Finland, the president

has traditionally enjoyed a more prominent executive and legislative role than most Western European heads of state. However, the new constitution of 1 March 2000 restricted the president's role, effectively formalising recent practical steps towards institutional relationships more typical of a parliamentary democracy. In future, the president's role will be largely ceremonial. Whereas the president formerly held supreme executive power, this is now shared with the cabinet (Council of State) of around fifteen ministers, headed by the prime minister. Whereas the president used to play a key role in the formation of governments, his or her role is now reactive: to appoint the prime minister selected by the unicameral Parliament (Eduskunta) and those ministers of the Council of State nominated by the prime minister. The prime minister directs the activities of the government. Legislative proposals are introduced in Parliament either by the government or by a private member. The Parliament appoints a parliamentary ombudsman to serve for a term of four years. The president still has a leading role in foreign policy, but must exercise this in co-operation with the Council of State. In other areas, the president must work to proposals submitted by the Council of State. On the request of the prime minister, the president may call an early election to the

Eduskunta. The president may be impeached on grounds of treason or of crimes against humanity.

Current government For the first time since independence in 1917, Finland saw a continuation of precisely the same governing coalition following the elections of March 1999. Prime
Minister Paavo Lipponen (SSDP) restored his five-party 'rainbow' coalition comprising SSDP/KOK/SFP/VAS/VIHR, arguing that a solid base of co-operation and ministerial experience would be needed for Finland's forthcoming EU presidency.

Electoral systems Following constitutional amendments from 1987, the president is elected by direct universal suffrage for a term of six years and may not serve more than two consecutive terms. If no presidential candidate obtains more than 50 per cent of the vote, a second ballot is held to determine the winner, in which only the two leading candidates of the first ballot may compete.

The 200-member Eduskunta is elected by a system of proportional representation for a four-year term.

Finnish presidential elections, 16 January and 6 February 2000

\begin{tabular}{lcc}
\hline & $\begin{array}{c}\text { First ballot } \\
(\%)\end{array}$ & $\begin{array}{c}\text { Second ballot } \\
(\%)\end{array}$ \\
\hline Tarja Halonen (SSDP) & 40.0 & 51.6 \\
Esko Aho (KESK) & 34.4 & 48.4 \\
Riitta Uosukainen (KOK) & 12.8 & \\
Elisabeth Rehn (SFP) & 7.9 & \\
Heidi Hautala (VIHR) & 3.3 & \\
llkka Hakalehto (True Finns) & 1.0 & \\
Risto Kuisma (Independent) & 0.6 & \\
\hline
\end{tabular}

Elections to the Finnish Eduskunta, 21 March 1999

\begin{tabular}{lcc}
\hline & Votes (\%) & Seats \\
\hline Finnish Social Democratic Party & 22.9 & 51 \\
$\quad$ (SSDP) & 22.4 & 48 \\
Centre Party (KESK) & 21.0 & 46 \\
National Coalition Party (KOK) & 10.9 & 20 \\
Left-Wing Alliance (VAS) & 7.3 & 11 \\
Greens (VIHR) & 5.1 & 11 \\
Swedish People's Party (SFP) & 4.2 & 10 \\
Finnish Christian League (SKL) & 6.2 & 3 \\
Others & & 200 \\
Total & & \\
\hline
\end{tabular}

Party system In common with other Western European countries, Finland's parties are largely divided by the class 
cleavage, with the VAS, SSDP and VIHR on the left, and KESK, KOK, SFP and SKL on the right. (The SKL changed its name to the Christian Democratic Party of Finland on 25 May 2001.) Unlike the practice in other countries, it has been common in Finland for the parties to co-operate across the class divide in broad-based coalition governments.

\section{France}

Population 58.9 million (2000)

Capital Paris

Territory 543,965 sq. km

GDP per capita US $\$ 23,276$ (2000)

(overseas territories excluded)

Unemployment 9.5 per cent of workforce (2000)

State form Republic, based on the constitution of 1958 establishing the Fifth French Republic. Following the liberation of France from German occupation in 1944 and a brief provisional government led by General Charles de Gaulle, the Fourth French Republic was founded in 1946. This regime, which proved unstable, was replaced in 1958 by the current one.

Current head of state President Jacques Chirac (took office 17 May 1995, re-elected May 2002).

State structure Unitary, comprising 96 metropolitan departments and 10 overseas departments. Corsica has its own directly elected legislative assembly.

Government The president appoints the prime minister and a cabinet (Council of Ministers) of around twenty members, which is responsible to the bicameral Parliament. Executive power is vested in the president, who is in practice the most politically powerful head of state in Western Europe. The president 'presides' over the Council of Ministers and may, under specified circumstances, dismiss the government ministers and accept the resignation of the prime minister; submit a bill to a referendum; declare emergency powers; and dissolve the lower chamber of Parliament, the National Assembly (Assemblée Nationale) once in a twelve-month period. The president makes appointments to senior civil and military posts. Throughout most of the Fifth Republic, the electorate has returned a majority supporting the party or coalition of the president to the National Assembly. This has enabled the president to be the effective executive leader of France.

Exceptionally, the electorate has instead returned a majority from the opposing 'bloc'. During these periods of 'cohabitation' (1986-88; 1993-95; 1997-2002), executive power has been shared between the president and the prime minister, with the latter commanding the support of the majority in the National Assembly. The constitutionality of bills is determined by the Constitutional Council.

Current government The first ballot of the French presidential election, held on 21 April 2002, shocked the nation when the candidate of the far-right FN took second place from the socialist leader and Prime Minister Lionel Jospin (PS). After this crushing defeat, Jospin stood down as head of the left-radical coalition government. In his place, President Jacques Chirac (RPR) named Jean-Pierre Raffarin (DL) as interim Prime Minister. After the parliamentary elections, Raffarin was confirmed as Prime Minister and on 18 June 2002 took office at the head of a government comprising RPR and DL. These parties had campaigned together during the parliamentary elections as the Union for the Presidential Majority (UMP).

Electoral systems From 1962 to 1995 , the president of France was elected 
by direct universal suffrage for a term of office of seven years. In September 2000 a referendum approved the reduction of the term of office to five years with effect from the presidential elections of 2002. If no presidential candidate obtains more than 50 per cent of the vote, a second ballot is held to determine the winner, in which only the two leading candidates of the first ballot may compete.

The National Assembly has 577 members: 555 for metropolitan France and 22 for the overseas departments. Members are elected by a single-member constituency system of direct election, using a second ballot if the first fails to produce an absolute majority for any one candidate. The term of office is five years.

The upper chamber of Parliament, the Senate, has 321 members, 296 for metropolitan France, 13 for the overseas territories and 12 for French nationals abroad. It is elected by an electoral college composed of members of the National Assembly and delegates from the councils of the departments and municipal authorities. Senators are elected for a nine-year term of office, but the Senate is not elected as a single body. Instead, one-third of the senators is elected every three years.

French presidential elections, 21 April and 5 May 2002

\begin{tabular}{lcc}
\hline & $\begin{array}{c}\text { First ballot } \\
(\%)\end{array}$ & $\begin{array}{c}\text { Second ballot } \\
(\%)\end{array}$ \\
\hline Jacques Chirac (RPR) & 19.9 & 82.2 \\
Jean-Marie Le Pen (FN) & 16.9 & 17.8 \\
Lionel Jospin (PS) & 16.2 & \\
Francois Bayrou (UDF) & 6.8 & \\
Arlette Laguiller (Workers' Struggle) & 5.7 & \\
Jean-Pièrre Chevènement (Citizen's & 5.3 & \\
$\quad$ Movement, MdC) & & \\
Noel Mamere (Green) & 5.3 \\
Alain Madelin (DL) & 3.9 & \\
Robert Hue (PCF) & 3.4 & \\
Others & 16.6 & \\
\hline
\end{tabular}

Elections to the French National Assembly, 9 and 16 June 2002

\begin{tabular}{lcc}
\hline & $\begin{array}{c}\text { Second ballot } \\
(\%)\end{array}$ & Seats \\
\hline Union for the Presidential Majority & 33.4 & 355 \\
$\quad$ (UMP (RPR and DL)) & & \\
Socialist Party (PS) & 23.8 & 140 \\
National Front (FN) & 11.1 & - \\
French Communist Party (PCF) & 4.9 & 21 \\
Union for French Democracy (UDF) & 4.8 & 29 \\
Greens (les Verts) & 4.4 & 3 \\
Radical Socialist Party (PRG) & 1.5 & 7 \\
Others & 16.1 & 22 \\
Total & & 577 \\
\hline
\end{tabular}

Elections to the French Senate, 23 September 2001 (resulting total distribution of seats in the Senate)

\begin{tabular}{lc}
\hline & Seats \\
\hline Rally for the Republic (RPR) and allies & 96 \\
Socialist Party (PS) and allies & 83 \\
Union of the Centre* & 53 \\
Republicans and Independents † & 40 \\
French Communist Party (PCF) and allies & 23 \\
Democratic and Social European Rally* & 19 \\
Independents (non-aligned) & 6 \\
Vacant & 1 \\
Total & 321
\end{tabular}

* mostly UDF † various right-wing groups

Party system During the years of the Fifth Republic, an initially fragmented party system has developed into a bipolar system of two main 'blocs' of parties on the centre-right and centre-left. Each bloc comprises many parties which frequently splinter and merge. For a time, these blocs were almost balanced in terms of electoral support, but recent elections show that their support is very unpredictable. The landslide defeat of the Socialist Party (PS), the main party of the centre-left, in the 1993 general election was followed by an impressive recovery in the first round of the presidential elections of 1995 . In the general election of 1997, a collapse in the vote of the centre-right, whose main parties are the RPR and UDF, was accompanied by a surge in support for the far right National Front (FN). In 2002, the FN's 
success in entering the second round of the presidential elections prompted a 'pro-republican' cross-party initiative to secure the centre-right candidate Chirac's election in the second round. Finally, in the parliamentary elections of 2002, the parties of the left (socialists, communists and greens) saw their vote share fall dramatically from 318 seats to 171 seats. This ensured the end of the period of 'cohabitation' between a centre-left government and the centre-right President Chirac which had begun in 1997. In spite of the evidence of growing support for the FN, the party lost its only parliamentary seat in the election of 2002.

\section{Germany}

Population 82.1 million (2000)

\section{Capital Berlin}

Territory 356,959 sq. km

GDP per capita US\$24,931 (2000)

Unemployment 7.9 per cent of workforce (2000)

State form Republic, based on the Basic Law of 1949, with subsequent amendments. The Federal Republic of Germany (FRG) was founded in 1949 from the three western zones of occupied Germany. On 3 October 1990, the territories of the former German Democratic Republic (GDR) and Berlin joined the federation and accepted the authority of the Basic Law.

Current head of state President Johannes Rau (took office 1 July 1999).

State structure Federation of 16 Länder, each of which has its own constitution, legislature and government.

Government The federal prime minister (chancellor) is elected by an absolute majority of the Parliament (Bundestag) and can only be dismissed if a successor is elected on the same occasion (a 'constructive vote of no confidence'). The chancellor selects a cabinet of around twenty members and the president formally appoints the chancellor and cabinet ministers. Executive authority rests with the federal government, which is responsible to the Bundestag. The Federal Council (Bundesrat) is composed of representatives of the governments of the Länder. Each Land sends between three and six delegates according to the size of its population, and may only vote en bloc. The Bundesrat may veto certain legislation. The president's activities are strictly defined and observed and include, under specified circumstances, the dissolution of the Bundestag. The Federal Constitutional Court (Bundesverfassungsgericht) determines the constitutionality of legislation and executive acts. Current government A centre-left coalition of SPD and Alliance 90/Greens led by Gerhard Schröder of the SPD.

Electoral systems The president is elected by the Federal Convention (Bundesversammlung), comprising the members of the Bundestag and an equal number of delegates elected by the Parliaments of the Länder. The candidate who wins an absolute majority of votes is elected. If no candidate secures an absolute majority in two ballots, a third ballot is held in which a relative majority is sufficient to win. The term of office is five years. A president may not serve more than two successive terms. The Bundestag is elected by direct universal suffrage. Since September 2002 the Bundestag has a standard complement of 598 seats, but the electoral system sometimes allocates surplus mandates. Half of the 598 seats are allocated to constituency candidates on the simple majority plurality ('first past the post') principle 
and the remainder by proportional representation based on party lists. Parties receive a share of seats in the Bundestag proportional to their share of party list votes, so that the electoral system is effectively one of proportional representation. The term of office is four years.

Election to the German Bundestag, 22 September 2002

\begin{tabular}{lcc}
\hline & Votes (\%) & Seats \\
\hline Social Democratic Party (SPD) & 38.5 & 251 \\
Christian Democratic Union (CDU) & 29.5 & 190 \\
Christian Social Union (CSU) & 9.0 & 58 \\
Alliance 90/Greens & 8.6 & 55 \\
Free Democratic Party (FDP) & 7.4 & 47 \\
Party of Democratic Socialism (PDS) & 4.3 & 2 \\
Others & 3.0 & 0 \\
Total & & 603 \\
\hline
\end{tabular}

Party system From 1961, only three parties won seats in the Bundestag: the CDU-CSU, the SPD and the small liberal FDP. The Greens entered the Bundestag in 1983 and the former GDR reformed communists, the PDS, followed after German re-unification in 1990. The formation of a red-green coalition under Schröder ended Helmut Kohl's 16-year incumbency as Chancellor for the CDU-CSU.

\section{Greece}

Population 10.6 million (2000)

Capital Athens

Territory 131,957 sq. km

GDP per capita US\$16,244 (2000)

Unemployment 10.9 per cent of workforce (2001)

State form Republic, based on the constitution of 1975. The liberation of Greece from German occupation in 1944 was followed by a civil war which lasted until 1949, when the communist forces were defeated and the constitutional monarchy restored. In 1967, a coup led by right-wing army officers took over the government and set up a façade democracy. The King went into exile, and, in 1973, Greece was declared a republic. In 1974, after a period of violent instability, former Prime Minister Konstantinos Karamanlis was invited to form a civilian government. A return to constitutional monarchy was rejected by referendum in December 1974. In June 1975, a new republican constitution was introduced, establishing a parliamentary democracy. Current head of state President Konstantinos Stefanopoulos (took office 10 March 1995).

State structure Unitary, with 10 regions. Government The president appoints the prime minister, and, on the prime minister's recommendation, the cabinet of around twenty members. In 1986, constitutional amendments reduced the office of president to a largely ceremonial one and transferred many of the president's former executive powers to the unicameral Parliament (Vouli ton Ellinon). The amendments restricted the president's right to call a referendum, transferred the right to call a state of emergency to Parliament, and removed the president's right to dismiss the prime minister. In addition, the president may now dissolve Parliament only if the resignation of two governments in rapid succession demonstrates a lack of political stability. The president may still ask Parliament to reconsider legislation, or to pass it with an enhanced majority.

Current government The incumbent PASOK, led by Kostas Simitis, narrowly won a third successive term in office at the election of April 2000. Simitis had called the election five months ahead of schedule to benefit from his government's good economic record.

Electoral systems The president is elected by Parliament for a term of five years.

The Vouli ton Ellinon has 300 
members and is elected by direct universal suffrage for a term of four years.

Election to the Greek Vouli ton Ellinon, 9 April 2000

\begin{tabular}{lcc}
\hline & Votes (\%) & Seats \\
\hline $\begin{array}{l}\text { Panhellenic Socialist Movement } \\
\quad \text { (PASOK) }\end{array}$ & 43.8 & 158 \\
New Democracy (ND) & 42.7 & 125 \\
Communist Party of Greece (KKE) & 5.5 & 11 \\
Alliance of Left and Progressive & 3.2 & 6 \\
$\quad \begin{array}{l}\quad \text { Forces (Synaspismos) } \\
\text { Democratic Social Movement } \\
\quad \text { (DHKKI) }\end{array}$ & 2.7 & 0 \\
Others & 2.1 & 0 \\
Total & & 300 \\
\hline
\end{tabular}

Party system The main parties are PASOK and the centre-right ND. The communist KKE has maintained a small presence in the party system.

\section{Iceland}

Population 281,000 (2000)

Capital Reykjavik

Territory 102,820 sq. km

GDP per capita US $\$ 27,608$ (2000)

Unemployment 2.3 per cent of workforce (2000)

State form Republic, based on the constitution of 17 June 1944, when Iceland declared its independence from Denmark.

Current head of state President Ólafur Ragnar Grímsson (first took office 1 August 1996, re-elected 2000).

State structure Unitary

Government The president appoints the prime minister and a cabinet of around ten members. Executive power is vested in the president and the cabinet, but in practice is exercised by the cabinet. The cabinet is responsible to the Parliament (Althingi), unicameral since 1991. Ministers may be impeached by the Althingi and tried by a court of impeachment. The president may dissolve the Althingi. In turn, the president may be dismissed by the
Althingi by a resolution supported by three-quarters of its members and confirmed by a referendum. If the president disapproves a law passed by the Althingi, it must be confirmed by referendum.

Current government The incumbent centre-right coalition of the Independence Party and Progressive party continued under the leadership of Prime Minister Davíd Oddsson (Independence Party).

Electoral systems The president is elected by direct universal suffrage for a term of four years.

The 63-member Althingi is elected by a system of proportional representation in eight constituencies. The term of office is four years.

Election to the Icelandic Althingi, 8 May 1999

\begin{tabular}{lcc}
\hline & Votes (\%) & Seats \\
\hline Independence Party & 40.8 & 26 \\
United Left & 26.8 & 17 \\
Progressive Party & 18.4 & 12 \\
Left-Green Alliance & 9.1 & 6 \\
Liberals & 4.2 & 2 \\
Others & 0.7 & 0 \\
Total & & 63 \\
\hline
\end{tabular}

Party system With the parliamentary election of May 1999, the Icelandic party system underwent its most radical restructuring since the Second World War. Only two parties gaining seats in the 1995 election competed in 1999 in the same form: the centre-right Independence Party and the centrist Progressive Party. The Social Democratic Party (including the People's Movement, which had broken away from the Social Democratic Party in 1994) joined forces with the radical Women's Alliance to contest the election under the umbrella of the United Left. Two further parties, the Left-Green Alliance and the Liberals, managed to win seats. The Left-Greens, a splinter group from the former left-socialist People's Alliance, formed to represent 
the increasing concerns for the environment from a leftist platform. The Liberals formed to contest the 1999 election essentially as a single-issue protest party concerned with fisheries policy.

\section{Ireland}

Population 3.8 million (2000)

Capital Dublin

Territory 70,283 sq. km

GDP per capita US $\$ 28,895$ (2000)

Unemployment 4.2 per cent of workforce (2000)

State form Republic, based on the constitution of 29 December 1937. Ireland was formerly part of the United Kingdom. In 1920 the island was partitioned, the six north-eastern counties remaining part of the UK. In 1922 the twenty-six southern counties achieved dominion status, under the British Crown, as the Irish Free State. In 1937, the new constitution was adopted by referendum, giving the Irish Free State full sovereignty within the Commonwealth. Formal ties with the Commonwealth were ended in 1949, when the twenty-six southern counties became the Republic of Ireland (Eire).

Current head of state President Mary McAleese (took office 11 November 1997).

State structure Unitary

Government The president summons and dissolves the bicameral Parliament on the advice of the government or prime minister (Taoiseach). On the nomination of the lower chamber of Parliament (Dáil Éireann), the president appoints the prime minister, and, on the advice of the prime minister and the Dáil, the cabinet of around fifteen members. The president is advised by a Council of State. The president may refer certain bills to the Supreme Court for a ruling on their constitutionality. With the support of a prescribed proportion of members of both chambers of Parliament, the president may refer certain bills to a referendum.

Current government Following the parliamentary elections of May 2002, the outgoing prime minister Bertie Ahern (FF) was confirmed at the head of his Fianna Fáil/Progressive Democrat coalition with the support of independents to secure the required vote of investiture. As before, the government programme featured the promotion of a lasting peace settlement in Northern Ireland and measures to ensure a strong economy.

Electoral systems The president is elected by direct universal suffrage for a term of office of seven years. The Dáil Éireann has 166 members and is elected by STV for a term of five years.

The upper chamber of parliament, the Seanad Éireann, has sixty members. Eleven are nominated by the prime minister, six are elected by the universities and forty-three by a broad-based electoral college. The term of office is five years.

Irish presidential election, 30 October 1997

\begin{tabular}{lcc}
\hline & $\begin{array}{c}\text { First count } \\
(\%)\end{array}$ & $\begin{array}{c}\text { Second count } \\
(\%)\end{array}$ \\
\hline Mary McAleese (FF) & 45.2 & 58.7 \\
Mary Banotti (FG) & 29.3 & 41.3 \\
Rosemary Scallon (independent) & 13.8 & \\
Adi Roche (LP) & 7.0 & \\
Derek Nally (independent) & 5.0 & \\
\hline
\end{tabular}

Election to the Irish Dáil Éireann, 17 May 2002

\begin{tabular}{llr}
\hline & $\begin{array}{c}\text { First preference } \\
\text { votes (\%) }\end{array}$ & Seats \\
\hline Fianna Fáil (FF) & 41.5 & 80 \\
Fine Gael (FG) & 22.5 & 31 \\
Labour (LP) & 10.8 & 21 \\
Sinn Féin & 6.5 & 5 \\
Progressive Democrats & 4.0 & 8 \\
Green Party (GP) & 3.8 & 6 \\
Others/Independents & 11.0 & 14 \\
Speaker & & 1 \\
Total & & 166 \\
\hline
\end{tabular}


Party system The two main parties, FF and FG, are both right of centre. Their differences stem from their positions on the Anglo-Irish Treaty establishing the Irish Free State (1921). This cleavage remains as a largely latent but significant cleavage in Irish politics. The anti-Treaty FF formed in 1926; the pro-Treaty FG in 1933. In 2001, the small Democratic Left (DL) joined with the larger left party LP. The other significant parties in the party system are the radical left-nationalist Sinn Féin and the conservative-liberal Progressive Democrats. In 2002, the Progressive Democrats renewed their alliance with FF to form the new government.

Italy

Population 57.2 million (2000)

Capital Rome

Territory 301,277 sq. km

GDP per capita US\$24,395 (2000)

Unemployment 10.5 per cent of workforce (2000)

State form Republic, based on the constitution of 1948. The constitutional framework of the previous regime, a constitutional monarchy, had remained in place throughout Mussolini's fascist dictatorship (1922-43) and was terminated by a national referendum held in June 1946. Current head of state President Carlo Azeglio Ciampi (took office May 1999).

State structure Unitary, with twenty regions, five with a special status. The regions each have an elected legislature and regional executive and enjoy a large degree of autonomy.

Government The president appoints the prime minister, and, on the prime minister's advice, the other members of the cabinet (Council of Ministers). The cabinet has around fifteen full ministers and is responsible to Parliament. The bicameral Parliament has a lower chamber, the Chamber of Deputies (Camera dei Deputati), of
630 members and an upper chamber, the Senate (Senato), of 315 elected members plus ten life senators, appointed by the president of the republic. The two houses of Parliament have equal powers. A constitutional court carries out the judicial review of legislation and judges accusations brought against the president of the republic or government ministers. For many years, a crisis of legitimacy had been building up in the Italian republic, centring on the endemic corruption of the traditional Italian political parties and their consequent failure to work within the institutions to provide strong, democratic government. In 1993, a series of scandals thoroughly discredited Italy's political elite. The crisis set in motion a meltdown and realignment of the party system and an ongoing attempt to bring about a fundamental reform of the country's political system. The project is hoped to lead to a speculative, improved 'Second Republic', but there are fears that the setbacks suffered may have cost the reform movement its impetus. A reform package introduced by the former centre-left government in June 1998 was blocked in the Chamber of Deputies by FI leader Silvio Berlusconi. Current government A radical right populist coalition led by Prime Minister Silvio Berlusconi (FI) and comprising the $\mathrm{FI} / \mathrm{AN} / \mathrm{LN} / \mathrm{CCD}-\mathrm{UCD}$ and allied small groupings.

Electoral systems The president of the republic is elected for a seven-year term of office by an electoral college made up of both chambers of Parliament and fifty-eight regional representatives.

New electoral systems for elections to the Chamber of Deputies and the Senate were introduced in 1993. These symbolised the reform process in Italy and were hailed by some as the start of a new Republic. The 
Chamber of Deputies has 630 members. Three-quarters (475) are elected on the single-member, single-ballot, plurality principle, as in the UK. The remaining 155 members are elected on a system of proportional representation based on twenty-seven districts, with a 4 per cent threshold.

The Senate has 315 elected members. Three-quarters (238) are elected by a majority vote in regional constituencies and the rest by proportional representation on a regional basis. The term of office for both the Chamber of Deputies and the Senate is five years.

At the 1996 elections, these new electoral arrangements proved so unsatisfactory that they were expected to be replaced with another alternative. However, on 18 April 1999, a referendum proposing new electoral systems failed as the turnout fell just short of the required 50 per cent plus one of the electorate.

Election to the Italian Chamber of Deputies, 13 May 2001

\begin{tabular}{lcr}
\hline & Votes (\%) & Seats \\
\hline House of Freedoms & 49.6 & 368 \\
Olive Tree Alliance & 35.0 & 250 \\
Refounded Communist Party (PRC) & 5.0 & 11 \\
Others & 10.4 & 1 \\
Total & & 630 \\
\hline
\end{tabular}

Election to the Italian Senate, 13 May 2001

\begin{tabular}{lcc}
\hline & Votes (\%) & Seats \\
\hline House of Freedoms & 42.5 & 177 \\
Olive Tree Alliance & 38.7 & 125 \\
Refounded Communist Party (PRC) & 5.0 & 3 \\
Others & 11.6 & 10 \\
Total & & 315 \\
\hline
\end{tabular}

Party system Italy's party system is currently in a state of flux. Widely discredited by the corruption scandals of 1993, the traditional parties found it impossible to continue under their old names and identities and were forced to reinvent themselves. In spite of this dramatic upheaval, there are strong elements of continuity in the emerging party system. Currently, the powerful House of Freedoms alliance represents a broad spectrum of parties of the right. It comprises Berlusconi's populist, pro-market and right-wing Forza Italia (the party name sounds like a football chant), the far-right National Alliance, the radical right separatist Northern League, the Christian Democratic Centre, the Christian Democratic Union and the New Italian Socialist Party. A similar grouping won the 1994 general election under the banner of the Freedom Alliance. House of Freedoms is opposed by an equally broad range of leftist and Green parties. It includes the Democratic Party of the Left (PDS); the La Margherita alliance (Italian People's Party, Democrats, Italian Renovation, South Tyrolean People's Party (SVP)); the Italian Communist Party; the Greens and the Italian Democratic Socialists.

\section{Luxembourg}

Population 439,000 (2000)

Capital Luxembourg-Ville

Territory 2,586 sq. km

GDP per capita US\$46,502 (2000)

Unemployment 2.4 per cent of

workforce (2000)

State form Constitutional monarchy, based on the constitution of 17 October 1868, as revised in 1919. The last subsequent amendment was on 12 January 1998.

Current head of state Grand Duke Henri (acceded April 2001).

State structure Unitary

Government After consulting the parliamentary party leaders, the Grand Duke nominates the prime minister (President of the Council) who must receive a vote of confidence from Parliament. The prime minister heads a cabinet (Council of Ministers) of around ten ministers, who must not simultaneously hold seats in 
Parliament. In theory, Parliament may dismiss the cabinet, but early dissolution is not now seen as a realistic option. The unicameral Parliament (Chamber of Deputies) has sixty members (since 1989). An advisory body of twenty-one members, the Council of State, reviews legislative proposals before they can be adopted by Parliament. The Council of State may delay legislation for up to three months and require Parliament to vote on it a second time.

Current government A coalition of the CSV/PCS and DP/PD under Prime Minister Jean-Claude Juncker was approved by the Grand Duke on 7 August 1999.

Electoral system The Chamber of Deputies is elected on a system of proportional representation based on four districts. The parties put forward lists of candidates and voters may choose to vote for a party list en bloc, or for individual candidates across party lists. Voting is compulsory. The term of office is five years (since 1959).

Elections to the Luxembourg Chamber of Deputies, 13 June 1999

\begin{tabular}{lcc}
\hline & Votes (\%) & Seats \\
\hline Social Christians (CSV/PCS) & 30.4 & 19 \\
Democratic Party (DP/PD) & 24.0 & 15 \\
Socialist Party (LSAP/POSL) & 22.6 & 13 \\
Action for Democracy and Pension & 9.4 & 7 \\
$\quad$ Justice (ADR) & & \\
Greens (déi Gréng) & 8.5 & 5 \\
The Left (déi Lénk) & 1.7 & 1 \\
Total & & 60
\end{tabular}

Party system The three main parties date from the turn of the twentieth century. The CSV/PCS have been in almost every government since 1945, with either the liberal DP/PD or the LSAP/POSL. Other parties include the Green Party (déi Gréng) formed in December 1994 from a merger of existing green groupings, and a single-issue party which campaigns for pension reform (ADR). With the elections of June 1999 there was a significant swing away from the LSAP/POSL and Green Party to the $\mathrm{DP} / \mathrm{PD}$, leaving the liberals - in opposition since 1984 - the second strongest party in the Chamber of Deputies and the chance of a return to government.

\section{Malta}

Population 379,000 (2000, estimate)

Capital Valletta

Territory 316 sq. km

GDP per capita US\$ 8,793 (1995)

Unemployment 5.3 per cent of workforce (2000)

State form Republic, based on the constitution of 1964, subsequently amended. Malta was a Crown Colony of the United Kingdom from 1814. In 1964 it adopted the Independence Constitution, becoming an independent sovereign state within the British Commonwealth. The constitution was amended in 1974, establishing Malta as a democratic republic within the Commonwealth. Further amendments in January 1987 protect Malta's neutrality and ensure that the party with the majority of votes forms the government. Current head of state President Guido de Marco (selected 4 April 1999).

State structure Unitary

Government The president appoints the prime minister, and, on the prime minister's advice, a cabinet of ten to fifteen ministers, the chief justice, the judges and the attorney-general. The cabinet can be dismissed by the unicameral, 65-member Parliament (House of Representatives).

Current government The majority Nationalist Party (NP) government under Edward Fenech Adami took office on 6 September 1998.

Electoral systems The president is elected by the House of 
Representatives for a term of five years.

The House of Representatives is elected by STV, based on thirteen constituencies. The term of office is five years.

Elections to the Maltese House of Representatives, 5 September 1998

\begin{tabular}{lcc}
\hline & Votes (\%) & Seats \\
\hline Nationalist Party (NP) & 51.8 & 35 \\
Malta Labour Party (PLM) & 47.0 & 30 \\
Democratic Alternative (AD) & 1.2 & 0 \\
Others & 0.1 & 0 \\
Total & & 65 \\
\hline
\end{tabular}

Party system The major parties are the NP and the PLM. Minor parties include the $\mathrm{AD}$ and the Malta Democratic Party (PDM). In 1998, the ousting of the PLM government under Alfred Sant put Malta back on course to join the EU. Malta's application for EU membership had been frozen by the PLM government.

\section{The Netherlands}

Population 15.9 million (2000)

Capital The Hague

Territory 33,937 sq. km (land only)

GDP per capita US $\$ 27,662$ (2000)

Unemployment 2.9 per cent of workforce (2000)

State form Constitutional monarchy, based on the constitution of 1814 and later revisions of 1848 and 1983. Current head of state Queen Beatrix (took the throne 30 May 1980).

State structure Unitary. The twelve provinces are each administered by a directly elected council, provincial executive and a sovereign commissioner, who is appointed by royal decree.

Government The monarch appoints a senior politician (informateur) to identify a potential prime minister, who, as a formateur, will form a coalition government. The monarch appoints the prime minister, and, on the advice of the prime minister, the other members of the cabinet. There is no formal vote of investiture for the cabinet, which has some fifteen members. Government ministers must not simultaneously hold seats in Parliament, but may attend Parliament and take part in debates there. The cabinet, under the prime minister, is responsible to Parliament. The Parliament (States-General) is bicameral. The lower chamber, confusingly termed the Second Chamber, has 150 members; the upper house (First Chamber) has 75 Legislation may be proposed by the Crown (as advised by a Council of State) and the lower chamber of Parliament. The Council of State must be consulted on all bills and draft general administrative orders. The First Chamber may approve or reject legislation, but not amend it.

Current government Until shortly before the May 2002 parliamentary election, the left-liberal PvdA/VVD/D66 government of the outgoing Prime Minister Wim Kok (PvdA) had been expected to be endorsed on the strength of a sound economic performance over the previous eight years. However, the assassination on 6 May 2002 of Pim Fortuyn, the controversial leader of the populist LPF, turned the campaign from economic issues to those of immigration, crime and anti-establishment issues. In a dramatic shift to the right, the CDA emerged as the largest party in Parliament with the LPF in second place, ahead of the PvdA. Support for the PvdA fell by almost half to return the party with just 23 seats. It was the party's worst defeat since the Second World War. The CDA's new leader, Jan Peter Balkenende, was expected to form a government coalition of the right, possibly with the LPF and VVD.

Electoral systems The Second Chamber is elected by a system of proportional 
representation based on national party lists. Its term of office is four years. The First Chamber is elected by members of the twelve provincial councils. Its term of office is six years, with half its members retiring every three years.

Elections to the Netherlands Second Chamber, 15 May 2002

\begin{tabular}{lcc}
\hline & Votes (\%) & Seats \\
\hline Christian Democratic Appeal (CDA) & 27.9 & 43 \\
Pim Fortuyn's List (LPF) & 17.0 & 26 \\
People's Party for Freedom and & 15.4 & 24 \\
$\quad$ Democracy (VVD) & 15.1 & 23 \\
Labour Party (PvdA) & 7.0 & 10 \\
Green Left (GL) & 5.9 & 9 \\
Socialist Party (SP) & 5.1 & 7 \\
Democrats '66 (D66) & 2.5 & 4 \\
Christian Union (CU) (christian & & \\
$\quad$ fundamentalist) & 1.7 & 2 \\
SGV (christian fundamentalist) & 1.6 & 2 \\
Livable Netherlands (populist) & 0.8 & 0 \\
Others & & 150 \\
Total & & \\
\hline
\end{tabular}

Party system The electoral landslide of 2002 rocked a party system which had been settling into one of four main parties: the PvdA, CDA, VVD and D66; and numerous small parties including the Green Left and the protestant fundamentalist parties, SGP and CU. The 2002 election brought two new populist parties into Parliament, with LPF, only three months old on election, likely to play a significant role in the party system at least for the current electoral period. The new parties represent anti-establishment as well as populist elements.

\section{Norway}

Population 4.5 million (2000)

Capital Oslo

Territory 323,878 sq. km

GDP per capita US $\$ 29,311$ (2000)

Unemployment 3.5 per cent of workforce (2000)

State form Constitutional monarchy, based on the constitution of 17 May
1814. Norway was formerly linked to the Swedish throne, but declared its independence in 1905 and elected its own monarchy.

Current head of state King Harald V (acceded on 17 January 1991).

State structure Unitary, with nineteen counties (Fylker)

Government The king appoints the prime minister, and, on the prime minister's advice, the cabinet (Council of Ministers) of around twenty members. The cabinet is responsible to Parliament. Ministers must not be members of Parliament, but they may attend and speak there. The unicameral Parliament (Storting) has 165 members. The Storting is elected as a single institution, but then chooses one-quarter of its members to form the upper chamber (Lagting) while the remainder form the lower chamber (Odelsting). Legislation is proposed in the Odelsting and requires the consent of both houses, but, if the houses disagree, can be passed by a joint session of the Storting by a two-thirds majority. Constitutional amendments must be passed by a two-thirds majority of a joint session. The king may veto legislation, but his veto may be overturned by three successively elected Stortings.

Current government A minority centre-right coalition of the Christian People's Party (KrF), the Conservative Party $(\mathrm{H})$, and the Liberal Party (V) won sufficient support in Parliament to form a government under Prime Minister Kjelle Magne Bondevik (KrF), which took office on 19 October 2001.

Electoral systems The Storting is elected by proportional representation based on district party lists; 157 members of the total 165 are constituency representatives, while the remaining eight are elected so as to achieve a greater degree of proportionality among the parties. The four-year term 
of office is fixed by the constitution and cannot be terminated early.

Election to the Norwegian Storting, 10 September 2001

\begin{tabular}{lcc}
\hline & Votes (\%) & Seats \\
\hline Labour Party (AP) & 24.4 & 43 \\
Conservative Party (H) & 21.2 & 38 \\
Progress Party & 14.7 & 26 \\
Christian People's Party (KrF) & 12.5 & 22 \\
Socialist Leff Party (SV) & 12.4 & 23 \\
Centre Party (Sp) & 5.6 & 10 \\
Liberal Party (V) & 3.9 & 2 \\
Coastal Party (TF) & 1.7 & 1 \\
Others & 3.6 & 0 \\
Total & & 165 \\
\hline
\end{tabular}

Party system The main parties are AP, the agrarian $\mathrm{Sp}$, conservative $\mathrm{H}$, christian democratic $\mathrm{KrF}$, the Progress Party, liberal V and the hard left SV. Since the early 1960s, government has usually fallen either to a coalition of centre-right parties or to a Labour minority government. After the elections of September 2001, the incumbent left-of-centre coalition was replaced by the opposition centre-right.

\section{Portugal}

Population 10.0 million (2000)

Capital Lisbon

Territory 92,072 sq. km

GDP per capita US $\$ 17,556$ (2000)

Unemployment 4.1 per cent of

workforce (2000)

State form Republic (since 1976).

Portugal's First Republic was declared in 1910, but in 1926 fell to a military takeover. This had given way by 1932 to the right-wing dictatorship of Antonio de Oliveira Salazar, led by Marcello Caetano after 1968. In April 1974, this regime was overthrown by the military group, the Armed Forces Movement (MFA). A liberal democratic regime was established with the constitution of 1976 . The substantial constitutional revision of 1982 removed the direct political influence of the military and reduced the president's powers; a further revision of 1989 removed the constitutional commitment to Marxist principles.

Current head of state President Jorge Sampaio (took office 9 March 1996).

State structure Unitary; the Azores and Madeira are autonomous regions.

Government The president appoints the prime minister, and, on the prime minister's advice, a cabinet (Council of Ministers) of around fifteen members. The cabinet's programme must win a vote of confidence from Parliament within ten days of taking office. The cabinet may be dismissed by the Parliament following a vote of no confidence. The unicameral Parliament, the Assembly of the Republic (Assembléia da República) has 230 members. The president may dissolve the Parliament. Legislation passed by Parliament is subject to judicial review by the Constitutional Court. The president may veto legislation. Parliament can overturn a presidential veto with an absolute majority of all its members. The Council of State is the political advisory body of the president. Current government After the elections of March 2002, the PSD formed a coalition government with the CDS/PP under PSD leader José Mañuel Durao Barroso, who became Prime Minister elect on 22 March 2002.

Electoral systems Presidential elections are by direct universal suffrage. The candidate who wins more than one half of the valid votes is elected. If no candidate achieves an absolute majority, a second ballot is held to decide between the two leading candidates of the first ballot. The term of office is five years. The president may not be re-elected for a third consecutive term of office. The Assembly is elected by a system of proportional representation, with a term of office of four years. 
Portuguese presidential elections, 14 January 2001

\begin{tabular}{lc}
\hline & Votes (\%) \\
\hline Jorge Sampaio (PS) & 55.8 \\
Ferreira do Amaral (PSD) & 34.5 \\
António Abreu (PCP) & 5.1 \\
Fernando Rosas (BE) & 3.0 \\
Garcia Pereira (MRPP) & 1.6 \\
\hline
\end{tabular}

Elections to the Portuguese Assembly, 17 March 2002 (excluding the autonomous regions*)

\begin{tabular}{lcc}
\hline & Votes (\%) & Seats \\
\hline Social Democratic Party (PSD) & 40.1 & 102 \\
Socialist Party (PS) & 37.8 & 95 \\
Democratic Social Centre/People's & 8.7 & 14 \\
$\quad$ Party (CDS/PP) & & \\
Communist Party (PCP) & 7.0 & 12 \\
Left Bloc (BE) & 2.7 & 3 \\
Others & 1.6 & 0 \\
Total & & 226 \\
\hline
\end{tabular}

${ }^{*}$ At the time of writing, the outcome for the autonomous regions (4 seats) was not known.

Party system Despite the revolutionary rhetoric of the 1976 constitution, party competition has been dominated by the centre-left PS and the centre-right PSD. On the radical left are the Portuguese Communist Party (PCP) and the Greens. The small CDS/PP is a conservative grouping. After the elections of October 1999, the incumbent Socialist Party (PS) remained in power under Prime Minister António Guterres. The PS was one seat short of an absolute majority, but was able to form a government with the parliamentary support of other parties of the left. With the election of 2002 the PSD overtook its rival the PS and was expected to form a government with the CDS/PP.

\section{Spain}

Population 39.5 million (2000)

Capital Madrid

Territory 504,782 sq. km

GDP per capita US\$19,194 (2000)

Unemployment 14.1 per cent of workforce (2000)

State form Constitutional monarchy. The constitution was adopted by national referendum in December 1978. The previous dictatorship of General Franco, established in 1939 following the three-year civil war, effectively ended on Franco's death in 1975. Current head of state King Juan Carlos I de Borbón (sworn in 22 November 1975).

State structure Unitary, but with considerable devolution of executive and administrative powers to seventeen elected regional assemblies. Government After consultation with the parliamentary party groups, the king appoints the prime minister (President of the Government), who must win a vote of confidence on his proposed government programme in the lower house of Parliament, the Congress of Deputies (Congreso de los Diputados). On the prime minister's advice, the king appoints a cabinet (Council of Ministers) of fifteen to twenty members. The cabinet is responsible to, and may be dismissed by, the Congress of Deputies. The Parliament (Cortes Generales) is bicameral, consisting of the 350-member Congress of Deputies and an upper chamber, the Senate (Senado) of 256 members. The prime minister may dissolve either or both houses of Parliament once in a twelve-month period. Legislation passed by the Cortes Generales is subject to judicial review by a constitutional court. Current government A majority government under the centre-right Popular Party (PP) led by Prime Minister José María Aznar.

Electoral systems The Congress of Deputies is elected by proportional representation for a four-year term. The electoral district is the province. 208 members of the Senate are elected by a majority system on a provincial basis, with four senators for every mainland province. The remaining senators, currently 48 , are chosen by the assemblies of the 
autonomous regions. The term of office is four years.

Elections to the Spanish Congress of Deputies, 12 March 2000

\begin{tabular}{lcc}
\hline & Votes (\%) & Seats \\
\hline Popular Party (PP) & 44.5 & 183 \\
Spanish Socialist Party (PSOE) & 34.1 & 125 \\
Convergence and Union (CiU) & 4.2 & 15 \\
United Left (IU) & 5.5 & 8 \\
Basque Nationalist Party (PNV) & 1.5 & 7 \\
Others & 10.2 & 12 \\
Total & & 350 \\
\hline
\end{tabular}

Elections to the Spanish Senate, 12 March 2000, elected members only

\begin{tabular}{lc}
\hline & Seats \\
\hline Popular Party (PP) & 127 \\
Spanish Socialist Party (PSOE) & 61 \\
Convergence and Union (CiU) & 8 \\
Basque Nationalist Party (PNV) & 6 \\
Canary Islands Coalition (CC) & 5 \\
Independent Party of Lanzarote (PIL) & 1 \\
Total & 208
\end{tabular}

Party system The main parties are the $\mathrm{PP}$ and the PSOE. Also significant is the far-left coalition, the United Left (IU), which includes the Communists. The main regionalist parties are the $\mathrm{CiU}$ and PNV. Numerous other small parties contest elections, many representing regional positions. In the election of March 2000 the PP scored the first majority victory for a centre-right party in contemporary democratic Spain. The party had previously been in a government coalition with $\mathrm{CiU}$ and PNV.

\section{Sweden}

Population 8.9 million (2000)

Capital Stockholm

Territory 449,964 sq. km

GDP per capita US $\$ 24,309$ (2000)

Unemployment 5.9 per cent of workforce (2000)

State form Constitutional monarchy. The constitution of 1975 replaced the outmoded version of 1809 . It was revised in 1979 to incorporate a new bill of rights.

Current head of state King Carl XVI

Gustaf (took the throne 15 September 1973).

State structure Unitary

Government After consultation with the parties represented in Parliament (Riksdag), the Speaker of the Riksdag proposes a candidate prime minister. The prime minister must receive a vote of confidence in the Riksdag before taking office. The prime minister appoints a cabinet (Council of State) of around twenty ministers, which is responsible to Parliament. Individual ministers may also be dismissed by Parliament. The Riksdag has been unicameral since 1969 and has 349 members.

Current government A minority government of the Social Democratic Labour Party (SAP) under Prime Minister Göran Persson (SAP), with parliamentary support from the Left Party (VP) and the Greens (MP), formed on 6 October 1998.

Election to the Swedish Riksdag, 20 September 1998

\begin{tabular}{lcc}
\hline & Votes (\%) & Seats \\
\hline Swedish Social Democratic Labour & 36.4 & 131 \\
$\quad$ Party (SAP) & & \\
Moderate Unity Party (M) & 22.9 & 82 \\
Left Party (VP) & 12.0 & 43 \\
Christian Democrats (KD) & 11.8 & 42 \\
Centre Party (C) & 5.1 & 18 \\
Liberals (Fp) & 4.7 & 17 \\
Green Party (MP) & 4.5 & 16 \\
Others & 2.6 & 0 \\
Total & & 349 \\
\hline
\end{tabular}

Electoral system The Riksdag is elected by a system of proportional representation based on districts. In order to win seats, parties must secure 4 per cent of the total vote or 12 per cent in one district. Of the 349 seats, 310 are permanent constituency seats and 39 are 'adjustment' seats, allocated to ensure that the distribution of seats in the Riksdag is proportionate to the total votes cast 
for each party. The term of office is four years (since 1994).

Party system The main parties are SAP, $\mathrm{M}$, the Fp, C and KD. Also significant are the Left Party (VP) (the former Communist Party, which changed its name in 1990), and the MP. The right-wing ND lost all of its twenty-five parliamentary seats in the 1994 election. The outcome of the 1998 election was a blow for the SAP, which received its worst share of the vote since 1928 . It nevertheless managed to negotiate sufficient parliamentary support to take office as a minority government.

\section{Switzerland}

Population 7.2 million (2000)

Capital Bern

Territory 41,293 sq. km

GDP per capita US $\$ 29,892$ (2000)

Unemployment 3.0 per cent of workforce (1999)

State form Republic, based on the constitution of 29 May 1874. A new constitution was accepted by popular referendum on 18 April 1999 and came into force on 1 January 2000. Although seen as a fundamental review, the new constitution did not substantially change the institutional framework of government in Switzerland. Amongst other measures, it abolished Switzerland's gold-standard status and enshrined the right to strike.

Current head of state President Kaspar Villiger (2002). The president and vice-president of the federation hold office for one year only and are chosen from the seven members of the Federal Council of the Swiss executive. They are elected by the Parliament, the Federal Assembly. The president's role is not comparable with any other Western European presidency. The Swiss president has no special political privileges, but performs the formal duties of a head of state together with formally chairing the Federal Council.

State structure Confederation of twenty cantons and six half-cantons.

Government The executive body, the Federal Council, consists of seven members, each from a different canton, who act as government ministers. These members represent a coalition of four parties which has been in power since 1959. The members of the Federal Council are elected by a joint session of the bicameral Parliament (United Federal Assembly) for a term of office of four years. Although the Federal Council is held 'responsible' to the Federal Assembly, the Federal Council may not be dismissed before the end of its term of office. The Federal Council is a collegiate body: there is no prime minister and most decisions are agreed by the Federal Council as a whole. The lower chamber of Parliament (National Council) has 200 members and represents the Swiss people. The upper chamber (Council of States), representing the cantons, has forty-six members, two from each canton and one from each half-canton. The lower and upper chambers have equal powers.

Referenda are crucial to the legislative process in Switzerland. On 4 March 2002 the electorate approved a referendum to join the UN, ending Switzerland's traditional stance of isolation. A formal application will be submitted at the UN General Assembly in September 2002. Current government The government does not hinge directly on election results, as in other Western European countries, but comprises the formula coalition, noted above, of the Christian Democratic Party of Switzerland (CVP), Social Democratic Party (SPS), the liberal Radical Democratic Party (FDP) and the agrarian right Swiss People's Party (SVP). 
Electoral systems Elections to the National Council are by proportional representation based on party lists. Each canton or half-canton forms one electoral district. The term of office is four years.

The method of election to the Council of States varies from canton to canton.

Elections to the Swiss National Council, 24 October 1999

\begin{tabular}{lcc}
\hline & Votes (\%) & Seats \\
\hline Social Democratic Party (SPS) & 22.5 & 51 \\
Swiss People's Party (SVP) & 22.5 & 44 \\
Radical Democratic Party (FDP) & 19.9 & 43 \\
Christian Democratic Party (CVP) & 15.9 & 35 \\
Green Party (GPS) & 5.0 & 9 \\
Liberal Party (LPS) & 2.3 & 6 \\
Others & 11.9 & 12 \\
Total & & 200
\end{tabular}

Party system In addition to the four main parties which make up the government coalition (CVP, SPS, FDP and SVP), a number of other parties contest general elections. These include the liberal LPS, Green GPS, Swiss Democrats (SD) (formerly known as National Action against Foreign Infiltration of the People and Homeland) and the evangelical EVP.

\section{United Kingdom}

Population 59.5 million (1999)

Capital London

Territory 244,103 sq. km GDP per capita US\$22,882 (1999)

Unemployment 6.6 per cent of workforce (2000)

State form Constitutional monarchy, without a written constitution. Current head of state Queen Elizabeth II (acceded 6 February 1952).

State structure Unitary, with differential devolution of powers to Scotland, Wales and Northern Ireland.

Government The monarch appoints the prime minister, usually the leader of the largest party in the lower house of Parliament, the House of Commons. The prime minister chooses a cabinet of around twenty members, who are appointed by the monarch. The House of Commons has 659 members. The incumbent Labour government is currently attempting a piecemeal reform of the upper house, the House of Lords. Traditionally, the House of Lords has had a variable membership of around 1,200. It was a non-elected body with three categories of member: hereditary and non-hereditary peers appointed by the monarch; archbishops and senior bishops of the Church of England; and law lords, who, within the House of Lords, performed the function of a final court of appeal. Reforms to date have concentrated on reducing the proportion of hereditary peers with automatic membership: 90 peers were elected in October 1999 and it is proposed that an increasing proportion of peers are to be appointed or elected to their seats or positions. The reform proposals are controversial and their outcome remains uncertain. As before, legislation must be passed by both houses and obtain royal assent. The House of Lords may delay legislation by up to a year. The prime minister may ask the monarch to dissolve Parliament at any time. Following legislation enacted in 1998, a system of devolution was introduced to the UK with the election of two new chambers in May 1999: the Scottish Parliament and the National Assembly for Wales. UK devolution is open-ended and is expected later to encompass the English regions. Although intended to incorporate the Northern Ireland Assembly, the status of devolution has in practice remained uncertain in Northern Ireland with the imposition of temporary suspensions. UK devolution is asymmetric in that the powers awarded to each of the devolved authorities differ in nature and in scope. 


\section{Current government A majority}

Labour Party government under Prime Minister Tony Blair.

Electoral systems The House of Commons is elected for a five-year term of office by a simple majority system of voting in single-member constituencies (first-past-the-post system). The Scottish Parliament and the National Assembly for Wales are elected on a system of proportional representation in which voters have two votes, one for a constituency contest and one for party lists, designed to ensure proportionality. Members of the Scottish Parliament are elected by a mixed system: 73 members represent single-member constituencies and are elected by a simple-majority vote and the remaining 56 are allocated according to an additional member system (AMS) so as to enhance proportionality in the Scottish Parliament. Members of the National Assembly for Wales are elected on similar principles: 40 members representing single-member constituencies are elected by simple-majority vote and 20 members by AMS on regional party lists. The Northern Ireland Assembly has 108 members elected on a proportional basis, with six members from each of the 18 constituencies of the central Westminster Parliament.

Party system The main parties are the Labour and Conservative Parties. The Liberal Democrats are the third national force. The Scottish National Party (SNP) and the Welsh nationalist Plaid Cymru attract regional support in Scotland and Wales respectively. Within Northern Ireland, the main parties are the Protestant Unionist parties (OUP, DUP, PUP and the Alliance Party) and the mainly Catholic Social Democratic and Labour Party (SDLP). The extreme nationalist Sinn Féin also contests elections.
Election to the UK House of Commons, 7 June 2001

\begin{tabular}{lcc}
\hline & Votes (\%) & Seats \\
\hline National parties & 42.0 & 412 \\
Labour Party & 32.7 & 166 \\
Conservative Party & 18.8 & 52 \\
Liberal Democrats & & \\
Regionally significant parties & $1.8\left(20.1^{*}\right)$ & 5 \\
Scottish National Party (SNP) & $0.7(14.3 \dagger)$ & 4 \\
Plaid Cymru & $0.8(26.8 \ddagger)$ & 6 \\
Ulster Unionist Party (UUP) & $0.7(22.5 \ddagger)$ & 5 \\
Democratic Unionist Party (DUP) & $0.7(21.7 \ddagger)$ & 4 \\
Sinn Féin & $0.6(21.0 \ddagger)$ & 3 \\
Social Democratic and Labour Party & & \\
$\quad$ (SDLP) & & 1 \\
Independent & & 1 \\
Speaker & & 659 \\
Total & & \\
* of votes cast in Scotland $\dagger$ of votes cast in Wales & $\ddagger$ of \\
votes cast in Northern Ireland &
\end{tabular}

Election to the Scottish Parliament, 6 May 1999

\begin{tabular}{lccc}
\hline & $\begin{array}{c}\text { First vote } \\
(\%)\end{array}$ & $\begin{array}{c}\text { Second vote } \\
(\%)\end{array}$ & $\begin{array}{c}\text { Seats } \\
\text { (total) }\end{array}$ \\
\hline Labour Party & 38.8 & 33.8 & 56 \\
Scottish National & 28.7 & 27.0 & 35 \\
$\quad$ Party (SNP) & & & \\
Conservative Party & 15.6 & 15.4 & 18 \\
Liberal Democrats & 14.2 & 12.5 & 17 \\
Others & 2.7 & 11.4 & 3 \\
Total & & & 129 \\
\hline
\end{tabular}

Election to the National Assembly for Wales, 6 May 1999

\begin{tabular}{lccc}
\hline & $\begin{array}{c}\text { First vote } \\
(\%)\end{array}$ & $\begin{array}{c}\text { Second vote } \\
(\%)\end{array}$ & $\begin{array}{c}\text { Seats } \\
\text { (total) }\end{array}$ \\
\hline Labour Party & 37.6 & 35.4 & 28 \\
Plaid Cymru & 28.4 & 30.5 & 17 \\
Conservative Party & 15.9 & 16.5 & 9 \\
Liberal Democrats & 13.4 & 12.6 & 6 \\
Others & 4.7 & 5.1 & 0 \\
Total & & & 60 \\
\hline
\end{tabular}

Election to the Northern Ireland Assembly, 25 June 1998

\begin{tabular}{lcc}
\hline & Votes (\%) & Seats \\
\hline Social Democratic and Labour Party & 22.0 & 24 \\
$\quad$ (SDLP) & & \\
Ulster Unionist Party (UUP) & 21.3 & 28 \\
Democratic Unionist Party (DUP) & 18.0 & 20 \\
Sinn Féin & 17.6 & 18 \\
Alliance Party of Northern Ireland & 6.5 & 6 \\
United Kingdom Unionist Party & 4.5 & 5 \\
Others & 10.1 & 7 \\
Total & & 108 \\
\hline
\end{tabular}




\section{INTERNATIONAL ORGANISATIONS IN WESTERN EUROPE}

\section{Council of Europe}

Established in 1949 in Strasbourg to promote unity between its members, to encourage their economic and social progress and to uphold the principles of parliamentary democracy and respect for human rights. The ten founding members were: Belgium, Denmark, France, Ireland, Italy, Luxembourg, the Netherlands, Norway, Sweden and the United Kingdom. There are now forty-one members including all the countries of Western Europe and a number of Eastern European countries. Other countries of Eastern Europe have applied to join.

The Council of Europe has an intergovernmental Committee of Ministers, whose members are usually the foreign minister of their respective member state, and which makes decisions unanimously. It usually meets twice a year. The consultative Parliamentary Assembly has 236 members and meets four times a year. The current Secretary-General of the Council of Europe is Dr Walter Schwimmer (Austria).

The European Convention for the Protection of Human Rights and Fundamental Freedoms was drawn up in 1950 on the recommendation of the Assembly and came into force in 1953. Under the Convention, the European Commission of Human Rights was established in 1954 to investigate alleged violations of human rights, and the European Court of Human Rights was set up in 1959.

\section{European Union (EU)}

The European Union has fifteen member states. Its institutions are in three sites: Brussels, Luxembourg and Strasbourg. The EU is regulated by the Treaty of Rome (1957), the later accession agreements for new member states, the Treaty on European Union (1993) and the Treaty of Amsterdam (1999).

The decision-making process within the $\mathrm{EU}$ is as follows: proposals originate in the Commission or European Parliament (EP) and are passed to the Council of Ministers (representing the member states), which must agree the proposals before they can come into effect. Once passed by the Council of Ministers, the Commission oversees the implementation of decisions. The EP debates issues, questions Commissioners and ministers, may amend parts of the budget and accept or reject the budget as a whole. It can dismiss the Commission en bloc. The Treaty of Amsterdam, which came into force in 1999, expanded and simplified the Parliament's legislative role. The current President of the Commission is Romano Prodi (Italy), who took office in July 1999.

Direct elections to the EP were introduced in 1979. Each member state uses its own electoral system to elect representatives on a five-year term. In 1995 the EP was expanded from a chamber of 567 members to one of 626 to encompass new members with the accession of Austria (21 MEPs), Finland (16) and Sweden (22). Similar to the development in the member state Parliaments, 'party groups' have formed within the EP. The main groupings are: christian democrats (European People's Party), Socialists, Liberal Group, Green/European Free Alliance, Confederal Group of the United Left, Union for a Europe of the Nations, Independents, the Europe of Democracies and Diversities and non-attached members. 


\section{North Atlantic Treaty Organisation (NATO)}

The Atlantic Alliance was established on the basis of the 1949 North Atlantic Treaty to provide common security for its members through co-operation in military, political and economic matters. The objectives of the Alliance are implemented by NATO, based in Brussels. The twelve founding members in 1949 were: Belgium, Canada, Denmark, France, Iceland, Italy, Luxembourg, the Netherlands, Norway, Portugal, the United Kingdom and the United States of America. Greece, Spain, Turkey and (West) Germany joined subsequently. Spain remained outside the Alliance's military structure until 1999. The status of France is somewhat unusual. It is a member of the Atlantic Alliance but opted out of the integrated military structure of NATO in 1966 and does not attend these meetings. In 1996, France resumed participation in some but not all of the military organs of NATO. Since the dissolution of the
Soviet-led Warsaw Pact in 1991, formerly regarded as the main adversary of the Atlantic Alliance, NATO has undergone radical restructuring in an attempt to meet the new security challenges in Europe. The Czech Republic, Hungary and Poland were formally admitted as members of NATO in March 1999, bringing membership to a total of nineteen members.

NATO has an intergovernmental North Atlantic Council. It is attended on a weekly basis by permanent representatives of the member states, and at least twice a year by member state foreign ministers or their heads of government and state. At all levels, it has effective decision-making authority and decisions are taken by common consent. NATO's Defence Planning Committee is convened twice a year at ministerial level and is attended by member state ministers of defence (although France does not send a representative). The current Secretary-General of NATO is Lord Robertson of Port Ellen (UK). 